Scientific note

\title{
A scientific note on Apis laboriosa winter nesting and brood rearing in the warm zone of Himalayas
}

Jerzy WOYKE ${ }^{\mathrm{a} *}$, Jerzy WILDE ${ }^{\mathrm{b}}$, Maria WILDE ${ }^{\mathrm{a}}$

a Dabur Apicultural Centre, Jugedi, Chitwan, Nepal

b WM University, Apiculture Division, Kortowo, Olsztyn, Poland

(Received 22 June 2001; revised 28 August 2001; accepted 12 September 2001)

Apis laboriosa / wintering / Himalayas / Nepal

The biology of Apis laboriosa Smith is little known. A. laboriosa lives in the Himalayas at altitudes of 1200-3500 m, where the living conditions are harsh, because the temperature drops in winter below $0{ }^{\circ} \mathrm{C}$. According to Roubik et al. (1985) nesting by A. laboriosa seems confined to areas higher than $2500 \mathrm{~m}$ in central and western Himalayas. Those authors concluded that nests built by $A$. laboriosa might be occupied throughout the year. However, Underwood (1990a,b) recorded that nest sites in the subalpine zones (above $2800 \mathrm{~m}$ ) are occupied by A. laboriosa only for 4 months in summer, while those within the warm zone (1200 to $2000 \mathrm{~m}$ ) may be used for as long as 10 months. By late November dropping temperatures make even the lower altitude cliff sites inhospitable and colonies must leave the cliffs (Underwood, 1990b). They survive December and January in the forest in energy-efficient, comb-less clusters near the ground.

We investigated wintering of A. laboriosa in the warm zone of Himalayas. We observed four cliff sites with A. laboriosa nests in the Himalayas in Nepal in November and December 1999. One site with 16 nests was located on the Annapurna slope in Kyumi at the Modi Khola river near Landrung in Kaski district (lat. $28^{\circ} 22^{\prime}$ N, long. $83^{\circ} 50^{\prime} \mathrm{E}$, alt. $1250 \mathrm{~m}$ ). This was probably the Landrung cliff site observed by Underwood (1990b). The observations were conducted here during six days, from November 27th to December 2 nd and again on December 20th. The other three rock cliffs were situated in Sindhupalchok district at the Bhote Koshi river near Tibetan border. One cliff with 53 nests was situated in Chale (lat. $28^{\circ} 09^{\prime} \mathrm{N}$, long. $85^{\circ} 48^{\prime} \mathrm{E}$, alt. $1500 \mathrm{~m}$ ), the other with 10 nests in Tatopani, $4 \mathrm{~km}$ north, on Tibetan riverside and the third with 6 nests still $3.5 \mathrm{~km}$ north before Kodari. Observations were conducted here on the 5th and 6th December, and again 23rd and 24th December. The Chale site was observed also earlier by Woyke 28th March 1988. In both places, at Annapurna slope and in Sindhupalchok district the bees were observed with the aid of $12 \times 50$ times binoculars from the other side of the river, from a distance of approximately $28 \mathrm{~m}$. Nests at the Kodari site could be approached to a distance of 3-5 m. Air temperature was recorded in Kyumi and Chale every hour from 8:00 to 16:00 h with the aid of electronic thermohygrometer.

Kyumi cliff site. During our winter observations in Kyumi from 27th November to 2nd December the temperature ranged from 6 to $24{ }^{\circ} \mathrm{C}$. The days were $10: 30 \mathrm{~h}$ long. On 1st December, sunrise, in the nearby Pokhara city was at $06: 44 \mathrm{~h}$ and sunset was at 17:13 h. At the cliff site, all 16 colonies occupied combs, and the bees were active. We observed foragers returning with pollen loads and workers collecting water from the river. Apparently, brood was being reared in those colonies. The colonies were harvested by local honey hunters 20th December. Brood of all ages and honey were present in all combs. Evidently, the colonies were not preparing themselves for abandoning the combs and for migration. Because colonies migrate when all or almost all brood emerges, those colonies would not migrate at least within 3 weeks it is till 10th of January. However, the amount of brood present and the young development stages, suggests that the colonies would occupy their combs for longer period.

* Correspondence and reprints: Agricultural University, Apiculture Division, 166 Nowoursynowska, 02-787 Warsaw, Poland.

E-mail: woyke @ alpha.sggw.waw.pl 
Sindhupalchok cliff sites. During our observations near the Tibetan border in Chale, from 5 th to 6th December, the temperature ranged from 8 to $17^{\circ} \mathrm{C}$. Of 53 colonies, six were adhering flat to the cliff. Apparently the flat ones were in the form of comb-less clusters. The other colonies on the combs were active. We observed foragers collecting pollen on flowers and returning to the nests with pollen loads. We noticed also worker bees collecting water. All 10 nests in Tatopani and the 6 near Kodari occupied big combs. On 23rd December, we found two additional colonies located at the mountain slop near the ground in the Chale site. Both were in the form of combs-less clusters. All colonies in Tatopani were harvested, and those near Kodari still occupied their combs. We harvested two colonies at the Chale cliff on 24th December. Brood of all ages and honey were present in combs from both colonies. Evidently, the colonies on combs were not preparing themselves for abandoning the combs and for migration.

The harvested brood was put in an incubator. Only worker bees emerged. Among 800 workers collected from one colony 6th December, we found only 1 drone, and among 866 collected from two colonies 24th December no drones were found. Evidently the colonies were not in reproductive swarming conditions.

Discussion and conclusions. Both observations, in Annapurna slope and in Sindhupalchok district show that many A. laboriosa colonies in the warm temperature zone of Himalayas (1200-2000 m) do not abandon their nest in December, but are active and rear brood. According to local information obtained in November and December, colonies in both places, in Kyumi and Chale already had occupied their combs for several months. Colonies observed by Woyke at the Chale site 28th of March 1998, all were on large combs. We judge they occupied the cliff at least for 1 month. This shows, that established A. laboriosa colonies in warm temperature areas below $1500 \mathrm{~m}$ do not abandon their nests in the winter months. A. laboriosa does not migrate below $1200 \mathrm{~m}$. The colonies find better living and survival conditions on their own combs than as comb-less clusters in the nearby forest. However we also found here some comb-less clusters. Bees present here in such conditions in winter, probably originated from robbed colonies, and/or those which migrated here from the cool areas above $2000 \mathrm{~m}$. The winter environment conditions did not stimulate those bees to start construction of new combs

Thus, during the winter, both comb-right colonies rearing brood, as well as comb-less clusters of A. laboriosa were found in the warm temperature zone (1200-2000 m) of the Himalayas. According to Underwood (1990b) colonies even at lower altitudes must leave the cliff sites by late November, to survive the winter in comb-less clusters. However, we found colonies on combs, rearing brood in late December, and they were not preparing themselves for abandoning the nests. We think the differences are due to the altitudes of the cliff sites observed. The lowest cliff sites monitored by Underwood for A. laboriosa migration were Chomrong and Kuli at altitudes of 1860 and 1710 m respectively, while we observed the Kyumi and Chale cliff sides at altitudes of 1250 and $1500 \mathrm{~m}$ respectively. This suggests that, colonies from the cool areas above $2000 \mathrm{~m}$ migrate for winter into the lower warm areas, where they pass some time in comb-less clusters. However, established colonies in the worm areas, below $1500 \mathrm{~m}$ do not abandon their nest in winter, but remain on their combs rearing brood during that season.

We are not sure whether A. laboriosa colonies, occupy their nest in the warm zone through the whole year. Roubik et al. (1985) found A. laboriosa foragers in August-September 1983, only above $1800 \mathrm{~m}$ and in July-September 1984 only above $2000 \mathrm{~m}$. We found abandoned dark old empty combs in both sites in the warm area. Perhaps in summer, some or all colonies abandon their combs in the warm zone and migrate to higher altitudes.

\section{ACKNOWLEDGEMENTS}

We would like to thank very much the chairman of the Dabur Company Mr. A.C. Burman for providing us the facilities to conduct these investigations in Nepal. We thank also M. Sci. Robert Kolasiński for his initiative to conduct research investigations in Nepal, and for his interest and help.

Note scientifique sur la nidification hivernale et l'élevage du couvain chez Apis laboriosa dans une région chaude de l'Himalaya.

Wissenschaftliche Notiz über die Überwinterung und Aufzucht von Brut bei Apis laboriosa im Himalaya.

\section{REFERENCES}

Roubik D.W., Sakagami S.F., Kudo I. (1985) A Note on nesting of the Himalayan honey bee Apis laboriosa Smith (Hymenoptera: Apidae), J. Kans. Entomol. Soc. 58, 746-749.

Underwood B.A. (1990a) The behavior and energetics of high-altitude survival by the Himalayan honey bee, Apis laboriosa, Ph.D. thesis, Cornell University, Ithaca, USA, 144 p., A. A. 1212/91.

Underwood B.A. (1990b) Seasonal nesting cycle and migration patterns of the Himalayan honey bee Apis laboriosa, Natl. Geogr. Res. 6, 276-290. 